\title{
Leadership Style Influence Employee's Work Commitment: A Conceptual Review In Padang Terap Community College
}

\author{
Hosni Mubarak Mohd Deris \\ Kolej Komuniti Padang Terap \\ Khodzirah Ahmad \\ Kolej Komuniti Padang Terap \\ Saidatul Azian Hashim \\ Kolej Komuniti Padang Terap \\ Reezlin Abd Rahman \\ Kolej Komuniti Sungai Petani
}

\begin{abstract}
This conceptual paper is to clarify the relationship between leadership style and employee's commitment at the Padang Terap Community College. Generally, there are two factors of leadership style that underpinning for this paper, namely the flexibility and initiative that are seen to influence work commitments in this organization. The review of this paper will provide the information, suggestion decision and contribution in addressing the situation that occurred at the Community College and thus help the management's plan for further research and appropriate changes.
\end{abstract}

Keyword: Leadership Style; Flexibility; Initiative and Commitment.

\section{INTRODUCTION}

Leadership style is a key factor influencing the work commitment of an organization [1]. The organizational management journey is measured by the success or failure from the result of the leadership. In fact, a good leadership affected employee's commitment to fulfil the organizational objectives [2]. In simple understanding, a high employee commitment will reflect the positive quality of work and ignoring the art of leadership style lead to the problems and difficulties for the organization in their daily operations [3].

Organizations that have a good leader must be responsible in managing and leading their staff toward achieving organizational goal [4]. Leadership style is seen as the art of a leader who can influence others, so that the subordinates can work together and effectively with less supervision [5]. The ability to work independently and voluntary show their true commitment as a sign in responding to the acceptance of the leadership style. In other hand, if there is a problem in an organization cause on lack of the ability to work together to achieve the objective, it is a sign of weakness in the leadership style and requires a changes in leadership effort and attitude [6].

\section{LEADERSHIP IN ORGANISATION}

Leadership generally refers to a person's ability to lead a group [7]. A competence in leadership will create a strong workforce and produce maximum work results [8]. The power of leadership can insist a positive or negative impact on his leadership skills. In detail, 
leadership is the word derived from a "leader" which means to guide, guidance or direct. In the same meaning, it refers to holding hands and walking to somewhere [9]. As the organizational perspective, [10] stated that leadership is the influence of the relationship between leaders and followers which reflects the purpose within the organization. It is a process or series of actions directed toward the goals of a group or organization [7]. Leadership is not only viewed as one action but involves a continuous pattern of behaviour designed to influence others to change their behaviour in achieving the organization's specific goals and objectives [4].

In the organization environment, those who are influenced are followers or employees who play an important role in achieving an organization's goals. It is important to understand that, without a follower, no leader would exist and sometimes, all leaders are also followers to the upper level leader [11]. The role of a leader in the organization is a decision maker, selectors, planners, trainers and influence his or her employees with a wide range of abilities and skills including to show employees how to achieve the organization's mission and objectives [2]. This skills ability causes the subordinates to voluntarily and willingly contribute their energy, emotion, and physical effort in an effort to achieve the mission and objectives of the organization [7]. Therefore, it is not only the leader's task to determine their objectives, but leaders also must create a conducive environment in order to employees feel safe, supported and willing to do their best in achieving the ultimate goals. In fact, the opportunities to lead others in achieving specific goal are considered recognition or a tribute to the leaders which is cannot be overlooked. Moreover, an understanding of the leader's positive attitude needs to be strengthened so that the belief in the leadership comes naturally to the worker's soul [11].

\section{LEADERSHIP STYLE}

The leadership style is a behaviour pattern used by the leaders from time to time to influence others [11] which determine the success or failure of an organization. [14] emphasize that leadership style is the process used by individuals who being selected as a leader to influence members of the group towards the achievement of the group's goals.

It is undeniable that leadership style has a strong influence on the aspects of increasing or decreasing employee commitment to the organization [3] and to achieve this, [12] recommended that leaders need to adopt a good leadership style which in line with the needs of employees and organizations in order to influence not only the values, attitudes, motivations, perceptions, roles and employees commitments, but also more important is the performance and effectiveness of the organization itself.

There are many leadership styles that have been articulated by past scholars including flexibility and initiative. Both of these styles are positive behaviours that will create a positive impact on the organization. Flexibility as stated by [13] as a flexible and adaptive leadership involves effort on the adaptable to changing circumstances. Leaders who are able to accurately diagnose situations and adapt to current solutions will make more relevant and accurate decisions. Whereas the initiative defined by [14] as a work behaviour that characterized by self-initiation, proactive approach, and persevering in overcoming the difficulties that arise in achieving the goal.

\section{Flexibility}

According to [15] flexibility comes from the root word meaning as elasticity, flexible or adaptable and can be changed or adapted easily to any situation. In the life realm, flexibility is a process of being willing to accept and change attitudes, decisions based on the current situation. The influence of flexibility on persons' life will also influence his ability to lead an organization [2]. 
Flexible leaders are the individuals who can be adaptable to the new environment [16]. He or she must adapt easily to a new place or setting that requires appropriate thinking and behaviour. The flexible leaders will be leading effectively by practice on varying ways of leading and always thinking outside the box and make good decisions towards changing circumstances and situations [17].

The fast changing business in current situation nowadays creates a sense of uncertainty in making and flexibility is an important aspect that must be taken into consideration in managing the problem of uncertainty [16]. Reflecting to that statement, a leader needs to adapt and must be able to change on their style in order to align with the current needs. Therefore, the traditional style of leadership may not be seen as an appropriate approach when applied to today's rapidly changing work environment. According to [11], an organization can be effective when its leaders can use all four leadership styles namely directing, coaching, supporting and delegating by integrating everything according to the circumstances. He added that a leader who can use these four styles in his leadership management symbolizes flexibility in his management skill.

\section{Initiative}

The ideal leader is a leader who dare to take the initiative when the organization faced a problem in daily operation. Initiative leaders are able to mobilize themselves first to get things started without the pressure [18]. In working environment nature, the strength of members to carry out the mission and vision of the organization will be more excited by looking at the examples set through by their leaders.

The initiative leader provides guidance to his subordinates and is ready to start first on what he feels right. For example, leaders who constantly motivate employees in the execution of tasks, share ideas of work to do and share the outcomes which are the important effort in boosting the work group's potential [19]. In a simple meaning, initiatives refer to the spirit needed to get a job started [20]. An initiative leader is a leader who sees more opportunities and has more vision than anyone else who is able to see things ahead of others [21]. The leaders must be able to think quickly and creatively to discover alternatives in designing and implementing programs or alternatives within an organization while maintaining a strong value, systems and discipline to create a dynamic organization [22]. Sometimes, the leaders also have to use futuristic mind [23] for the future growth of the organization.

\section{Work Commitment}

Commitment occurs through from the individual's action who give the full support in term of energy and attention to certain task [24]. In leadership perspective, commitment refers to an individual or group that demonstrates a dedication to his work [7]. A leadership commitment is closely related to the atmosphere of the relationship in the organization, including the relationship with the supervisor and subordinates. A good relationship with the staff will give them a value added to be more easy to work with, beside applying higher productivity and more proactive in supporting the organization [6].

In the other view, employee commitment according to [24] refers to the level of willingness of employees to remain as a staff of the organization, the willingness to work hard on behalf of the organization, to have a strong belief and to be able to accept the values and goals of the organization. [25] defines employee commitment as the confidence, willingness and motivation of employees to perform and complete each task while in the organization. Excellent employee commitment requires efforts such as affective commitment, normative commitment and continuance commitment [26]. According to him, employees with affective 
commitment will feel satisfied with the work they do. On the other hand, employees with normative commitment often feel that leaving their organization will have an adverse effect on the organization. Furthermore, employees with a continuance commitment will feel the need to stay within the organization due to work demands or the pleasure of working due to the leadership style within the organization.

In the same way, [12] see that motivated employees will perform better and will indirectly influence organizational success performance while also enhancing the motivation of other staff to perform well. This is in line with the need of the organization whereby employee's commitment is essential, in order to ensure that organizational goals are achieved aligned with individual commitment which as one of the mechanisms for measuring the organization success [27]. In conclusion, a commitment from leaders with the committed employees show a positive significant to the organization that increased proactive support each other, high productivity and work quality.

\section{PADANG TERAP COMMUNITY COLLEGE}

Padang Terap Community College (KKPT) is one of 103 Community Colleges run by the Ministry of Education Malaysia was established on April 11, 2011 that located at Belimbing Indah Park, 06300 Kuala Nerang, Kedah Darul Aman. This college offered two (2) full-time courses; 1) Certificate of Electrical Wiring and; 2) Certificate of Computer Network which the first enrolment has started on July 2012 session.

Currently, the Padang Terap Community College has 29 staff led by Director and assisted by two deputy directors that also catered not only to the full time students, but also for the communities through lifelong learning education. From 29 staffs, 14 are from a dynamic and competent academic staff that are in charge of all matters related to academic management and lifelong education. Meanwhile 15 staffs are in charged in the administration section.

\section{DISCUSSION}

Highly committed employees are essential for an organization to carry out an organization's mission and vision. Each employee specifically a civil servants responsible for implementing the work that has been designated as the duties and functions of a position appointed by the circular of civil servants in Malaysia. The implementation of the work by civil servants is subject to the direction of the organization's management from time to time based on the government agenda [16]. In addition, the civil servant's leaders who are appointed to lead an organization are often seen as talented, well-trained and qualified to manage an organization. In a civil staff side and in reality work, there are still employees who fail to perform their jobs or commit to work due to non-compliance with management needs. This may be due to organizational management style that is not compatible with gender, education, position, age, expertise and other factors that may contribute to the failure to accept and cooperate within an organization [4].

Unfortunately, some employees protest against the instructions that they receive because of a lack of regulation and management action [28]. Sometimes, the instructions are not clear that can cause work required cannot be implemented with full commitment. Poor and uncooperative leaders and employees can also cause prolonged conflicts and thus affect the planning and execution of work within the organization [26]. In sum, the negative perceptions among employees toward organizational leaders lead to the unsupported task and negatively impact to the unsuccessful objectives. 
Leadership style is important in the civil servant organization management [29,24]. A good leader is someone who is capable of engaging in the diversity of his or her workforce and situation or flexibility [22]. In other words, an ideal leader must also have full trust in the employee and be open to any issues or problems within the organization [8].

The leaders are also must be able to be initiative and responsible in determining their direction by taking the role in ensuring the work is done as a [2]. He or she must be willing to move together and offer it help and suggestions as well as a facilitator for the working group or subordinate to carry out the assignment [27].

Based on the explanation on the above statement, there are some issues that been refined occurs in Padang Terap Community College from the management side such as; a) the instructions and roles are unclear, b) disrespectful attitude towards less capable employees; c) There is no firmness and urge for work to be done properly; d) unsupported by the management in problem solving and; e) Bad perception staffs to the management.

In the staff or subordinate issue; a) failure of teamwork; b) no sense of responsibility for a job; c) no readiness to change in work; d) doing other job while on duty such as running personal business. Inclusive of all issues above, it is no wonder that the organizational operating cannot be driven smooth, effectively and efficiently

Based on the assumptions of this style of leadership, there are a some questioned that need to be addressed in resolving the issues that can be addressed; i) Does the influence of flexibility in management affect staff commitment at the Padang Terap Community College?; ii) Does the influence of initiative in management affect staff commitment at the Padang Terap Community College?; iii) Do high commitment from the leaders reflect staff work commitment at the Padang Terap Community College? Based on these questions, this study needs to be done to assist the management of the Padang Terap Community College in improving the quality of work and thus achieving the mission and vision of the department.

Based on the above questions, the framework with hypothesis has derived along with the suggestions of variables to make this study more focused.

\section{Framework}

\section{EXPERIMENTS AND ANALYSIS}

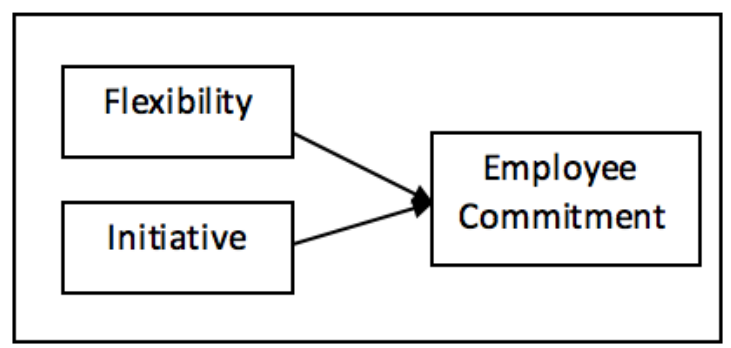

\section{Hypothesis}

1. There is a significant relationship between flexibility and employee commitment in organizational management at the Community College.

2. There is a significant relationship between initiative and employee commitment in organizational management at the Community College. 


\section{Research Objective}

1. To identify the relationship between flexibility and employee commitment in Padang Terap Community College.

2. To identify the relationship between initiative factors and employee commitment at the Community College.

\section{Research Questions}

1. Is there a relationship between flexibility and employee commitment in Padang Terap Community College?

2. Is there a relationship between the initiative and the employee commitment of workers in Padang Terap Community College?

\section{STUDY INTEREST}

The findings of this study can assist the management to identify the leadership style needed in an organization especially in the Padang Terap Community College. Furthermore, the study will strengthen the theory that leadership style has a strong influence on an organization and contributes to the body of knowledge.

On the organizational side, this study is expected to provide a clear picture of leadership style at the Padang Terap Community College and to develop strategies for improving the leadership style in the organization in solving the problems identified that can create a harmonious working environment among management and subordinates.

\section{References}

A.Kisling, R. (2007). Character for Leadership :The Role of Personal Characteristics in Effective Leadership Behaviors. (Character for Leadership).

Ahmad, A. D., \& Bach, C. (2014). Major Traits / Qualities of Leadership. 3(International Journal of Inovation and Scientific Research).

Blau, G. (1985). The Measurement and Prediction of Career Commitment. 58 (277)(Journal of Occupational Psychology)

Carmeli, A., \& Anat, F. (2004). Work Commitment, Job Satisfaction, And Job Performance: An Empirical Investigation. 6 (4)(International Journal Of Organization Theory And Behavior).

Fleenor, J. W. (2011). Trait Approach to Leadership. (Encyclopedia of Industrial and Organizational Psychology) Howell, J.P., and D.L. Costley (2001). Understanding Behaviors for Effective Leadership. Saddle River, NJ: PrenticeHall

Winston, B. E., \& Kathleen, P. (2006). An Integrative Definition of Leadership. Vol. 1 Iss. 2, pp. 6-66(International Journal of Leadership Studies).

Mansor, R., \& M.Hamzah, M. (2015). Kepimpinan Berkualiti : Perspektif Mengenai Kompetensi Yang Diperlukan Untuk Memimpin Dengan Berkesan. 45(Jurnal Pengurusan).

Larsson, J., \& Vinberg, S. (2010). Leadership Behavior In Successful Organisations : Universal or SituationDependent? (Total Quality Management \& Business).

Jon P. Howell and Dan L. Costley. (2001). Understanding Behaviors for Effective Leadership. US: Prentice-Hall.

Blanchard, K. (2001). A retrospective of leadership th eory: Situational leadership and situational leadership II. San Diego, CA: Ken Blanchard Companies.

M.Bass, B. (1985). Leardership and Performance Beyond Expectation. 191.

Yukl, G. (2006). "Leadership in organizations". New Jersey: Pearson-Prentice Hall.

Hao, M. J., \& Yazdanifard, R. (2015). How Effective Leadership Can Facilitate Change In Organizations Through Improvement And Innovation. Global Journal Of Management And Business Research.

Kamus Dewan. Edisi keempat, Kuala Lumpur: Dewan Bahasa dan Pustaka, 2010. 
Eapen, G. (2010). Flexibility ; Flexible Companies for the Uncertain Word. USA: Taylor \& Francis Group.

H.Burtch, P. (2011). The Effect of Leadership Flexibility and Effectiveness on City Manager Tenure.

Ismail, N., \& Zainal Abiddin, N. (Mei 2010). Tinjauan Faktor-faktor Yang Mempengaruhi Komitmen Pekerja Terhadap Organisasi. 6(Dinamika Sosial Ekonomi).

T.S, N. (2014). Leadership Styles. 7(Advances In Management).

Mohamad, B., Esa, A., Ab.Hadi, M., Hashim, J., \& Mohamad, M. (2009). Teori Kepimpinan Fleksible Sebagai Alternatif Kepada Pencapaian Cemerlang Sekolah Pada Dekad 2020 :Satu Model Konsep. (Seminar Kebangsaan Pengurusan Pendidikan PKPGB).

Mohamad, M., \& Zainal Abiddin, N. (Mei 2011). Hubungan Budaya Organisasi Dan Sub Budaya Terhadap Komitmen Pekerja. 7(Dinamika Sosial Ekonomi).

R.DiLella, A. (2018). A Study Of Principals' And Assistant Principals' Self-Perceived Leadership Behaviors In Relation To The Pennsylvania Inspired Leadership Initiative.

R.Furr, N. (2009). Cognitive Flexibility : The Adaptive Reality of Concrete Organization Change.

Mowday, R. T., Steers, R. M., \& Porter, L. W. (1979). The measurement of organizational commitment. 14(Journal of Vocational Behavior).

Isa, K. (2013). Kesan Komitment Pekerja Terhadap Hubungan Antara Tingkah Laku Kepimpinan dan Keberkesanan Organisasi.

Mayer, J. P., J. Allen, N., \& A.Smith, C. (1993). Commitment to Organizations and Occupations: Extension and Test of a Three-Component Conceptualization. 78(Journal of Applied Psychology).

A.Rahman, N. M., \& Muhamad, N. (2001). Komitmen dan Kepuasan Kerja Pekerja di Dua Jenis Organisasi. 20(Jurnal Pengurusan).

Hassani, Z., Silong, A., \& Muslim, N. (2009). Kepimpinan Beretika dan Kecemerlangan Organisasi dalam Perkhidmatan Awam. 10(MALIM).

Ramli, N., \& Abdul Hamid, J. (2006). Gaya Kepimpinan Pengetua Wanita dan Hubungannya dengan Tahap Motivasi Guru Sekolah Menengah. 31(Jurnal Pendidikan). 